\title{
PENYELESAIAN SENGKETA KEPEGAWAIAN AKIBAT PENJATUHAN HUKUMAN DISIPLIN
}

\author{
Ade Kosasih \\ Lembaga Konsultasi dan Bantuan Hukum IAIN Bengkulu \\ Jl. Raden Fatah Pagar Dewa Bengkulu \\ Email: adeindrakosasih@gmail.com
}

\begin{abstract}
An understanding of the rights and efforts that civil servants can take in facing employment disputes arising from the imposition of disciplinary punishment of civil servants, needs to be improved in order to avoid the act of arbitrariness (or willekeur) or action beyond the authority (ultra vires) conducted by the organ of state administrative office. The mechanisms and stages of dispute resolution in the field of personnel, has a variety of channels based on disciplinary violations committed, types of sentences handed down, and the level of position of officials who are authorized to punish. These channels, some through the Administrative Objections and Administrative Appeals. If only through Administrative Objection, then the next stage is the filing of a lawsuit to the State Administrative Court, whereas if the stages are through Administrative Appeals, the first level lawsuit shall be submitted to the Administrative High Court as a first instance court.
\end{abstract}

Keywords: dispute, staffing, disciplinary punishment

\begin{abstract}
Abstrak: Pemahaman mengenai hak-hak dan upaya-upaya yang dapat ditempuh oleh Pegawai Negeri Sipil (PNS) dalam menghadapi sengketa kepegawaian yang timbul akibat penjatuhan hukuman disiplin PNS, perlu untuk ditingkatkan agar terhindar dari tindakan sewenang-wenang (willekeur) atau tindakan melampaui kewenangan (ultra vires) yang dilakukan oleh organ jabatan tata usaha negara. Adapun mekanisme dan tahapan penyelesaian sengketa di bidang kepegawaian tersebut, memiliki jalur yang beragam berdasarkan pelanggaran disiplin yang dilakukan, jenis hukuman yang dijatuhkan, dan jenjang jabatan pejabat yang berwenang menghukum. Jalur-jalur tersebut, ada yang melalui upaya Keberatan Administratif dan Banding Administratif. Jika yang dilaluinya hanya Keberatan Administratif, maka tahapan selanjutnya adalah pengajuan gugatan ke Pengadilan Tata Usaha Negara, sedangkan jika tahapan yang dilaluinya adalah Banding Administratif, maka gugatan tingkat pertama diajukan kepada Pengadilan Tinggi Tata Usaha Negara sebagai pengadilan tingkat pertama.
\end{abstract}

Kata kunci: sengketa, kepegawaian, hukuman disiplin

\section{Pendahuluan}

Sejak awal persiapan kemerdekaan Indonesia, para founding father telah mufakat untuk menentukan konsep negara Indonesia adalah negara kesejahteraan (wevaar staat/wefare state) bukan negara liberal (nachtwaaker staat). ${ }^{1}$ Menurut Muchsan, karakter negara kesejahteraan Indonesia terbukti dari salah satu sila dari Pancasila sebagai dasar falsafah negara (sila Kelima) adalah keadilan sosial. Ini berarti

${ }^{1}$ Lihat Sekretariat Negara Republik Indonesia, Risalah Persidangan BPUPKI dan PPKI tanggal $28 \mathrm{Mei}-22$ Agustus 1995, (Jakarta: Sekretariat Negara, 1995), h. 25. tujuan negara adalah menuju kesejahteraan dari para warganya. Selain itu, dalam alinea Keempat Pembukaan UUD 1945 dikatakan bahwa tujuan pembentukan negara Indonesia adalah "melindungi segenap bangsa Indonesia dan seluruh tumpah darah Indonesia, memajukan kesejahteraan umum, mencerdaskan kehidupan bangsa dan ikut melaksanakan ketertiban dunia yang berdasarkan kemerdekaan, perdamaian abadi dan keadilan sosial". ${ }^{2}$

Guna mencapai tujuan negara tersebut maka

2 Muchsan, Pengantar Hukum Administrasi Negara, (Yogyakarta: Liberty, 1982), h. 70. 
dalam penyelenggaraan negara, dibutuhkan instrumen atau sarana negara. Sarana negara dimaksud terdiri dari sarana yuridis, sarana personil, sarana materiil dan sarana finansial. ${ }^{3}$ Sarana yuridis yaitu produk hukum baik yang berupa peraturan perundang-undangan (regeling), peraturan kebijaksanaan (bellieds regel), penetapan administrasi (beschikking), ${ }^{4}$ yurisprudensi, dan kontrak atau perjanjian. ${ }^{5}$ Sarana personil yang dimaksud adalah penyelenggara negara baik pejabat politik, hakim, pegawai negeri sipil, pegawai BUMN/BUMD, dan petugas publik lainnya. ${ }^{6}$ Sarana materiil adalah segala sesuatu peralatan atau perlengkapan yang dibutuhkan dalam penyelenggaraan negara. Sedangkan sarana finansial meliputi semua sumber-sumber pendapatan keuangan negara yang berguna bagi pembiayaanatau belanja operasional dan pembangunan yang dilaksanakan oleh sarana personil.

Di dalam negara kesejahteraan (welvaar staat), peran sarana personil atau lebih lazim disebut aparatur negara sangat penting khususnya Pegawai Negeri Sipil (PNS). Kedudukan PNS dalam penyelenggaraan pemerintahan merupakan garda terdepan negara dalam memberikan pelayanan kepada warga negara. Oleh sebab itu, PNS dituntut agar bekerja secara profesional dan akuntabel dalam melaksanakan fungsi, tugas, dan kewenangan yang diberikan negara kepadanya.

Untuk menjaga profesionalitas, akuntabilitas, dan integritas PNS, Pemerintah telah memberikan pedoman yang jelas dalam peraturan perundangundangan yang berlaku. Misalnya terkait dengan hak, kewajiban, fungsi, tugas, peran, dan kedudukanPNS telah diatur di dalam Undang-

3 Y. Sri Pudyatmoko, Hukum Administrasi Negara, (Yogyakarta: Atma Jaya, 2012), h. 24.

${ }^{4}$ Sering juga disebut keputusan walaupun secara etimologi keputusan dalam bahasa Belanda adalah besluit yang unsur dan karakternya berbeda dengan penetapan administrasi (beschikking).

${ }^{5}$ Lihat Ade Kosasih, Formula Praktis Memahami Teknik \& Desain Legal Drafting, (Bogor: Herya Media, 2015), h. 9.

${ }^{6}$ Lihat Philipus M. Hadjon, Pengantar Hukum Administrasi Indonesia, (Yogyakarta: UGM Press, 2003).
Undang Nomor 5 Tahun 2014 tentang Aparatur Sipil Negara. Sementara mengenai pembinaan semangat dan perilaku Pegawai Negeri Sipil, diatur dalam Peraturan Pemerintah Nomor 42 Tahun 2004 tentang Pembinaan Jiwa Korps dan Kode Etik Pegawai Negeri Sipil. Khusus mengenai perilaku Pegawai Negeri Sipil yang terkait dengan kedisiplinan diatur dalam Peraturan Pemerintah Nomor 53 Tahun 2010 tentang Disiplin Pegawai Negeri Sipil.

Adanya pedoman yang jelas yang dituangkan ke dalam peraturan perundang-undangan, ternyata tidak menjamin PNS berkerja secara profesional dan akuntabel. Bahkan sering dijumpai pelayanan prima yang menjadi slogan di setiap lembaga pemerintahan tidak sesuai dengan kenyataan. Pelayanan yang seharusnya dapat dituntaskan untuk jangka waktu tertentu sesuai Standar Pelayanan Minimal (SPM) justru sebaliknya, memakan waktu lebih lama. Salah satu kendala yang sering ditemui adalah tidak adanya PNS yang bertugas di tempat. Akibat lebih lanjut, pelayanan publik (public service) menjadi terhambat, sehingga masyarakat dirugikan.

Terhadap PNS yang melanggar peraturan disiplin tentunya harus dihukum sesuai dengan peraturan disiplin PNS. Namun terhadap penjatuhan hukuman disiplin tersebut sering kali terjadi sengketa antara PNS dengan organ jabatan yang berwenang menjatuhkan hukuman yang dikenal dengan istilah sengketa kepegawaian. Sengketa kepegawaian terjadi dikarenakan adanya perbedaan pendapat mengenai penerapan hukum yang berujung pada penjatuhan hukuman disiplin.

Di satu sisi organ jabatan yang berwenang menjatuhkan hukuman menganggap bahwa penjatuhan hukuman disiplin sudah sesuai dengan peraturan perundang-undangan yang berlaku. Di sisi lain PNS yang bersangkutan menganggap proses penjatuhan hukuman disiplin tidak mengacu pada peraturan perundang-undangan yang berlaku, atau dalam penjatuhan hukuman organ jabatan tersebut tidak memperhatikan 
asas-asas umum pemerintahan yang baik/layak ${ }^{7}$ (algemene beginselen van behoorlijk bestuur) atau etika birokrasi sehingga bertindak sewenangwenang (willekeur), atau bisa jadi organ jabatan tersebut telah melampaui kewenangan yang dimilikinya (ultra vires). Misalnya, seorang PNS tidak masuk kerja tanpa keterangan dalam kurun waktu tertentu dan dijatuhi hukuman disiplin telah sesuai Peraturan Pemerintah Nomor 53 Tahun 2010 tentang Disilin Pegawai Negeri Sipil. Namun, penjatuhan hukuman tersebut dirasakan tidak adil bagi PNS yang bersangkutan jika sebelumnya PNS tersebut tidak pernah dipanggil untuk dimintai keterangan atau alasan keaalpaannya. Hal tersebut jelas bertentangan dengan asas-asas umum pemerintahan yang layak dalam hal ini asas kewajiban mendengarkan para pihak (audi alterm partem), asas permainan yang adil (fair play) dan asas kecermatan (principle of carefulness).

Tidak diperhatikannya asas-asas umum pemerintahan yang layak (algemene beginselen van behoorlijk bestuur) dapat menyebabkan Keputusan Tata Usaha Negara yang berisi penjatuhan hukuman disiplin tersebut menjadi batal atau tidak sah. Hal ini dikarenakan berdasarkan ketentuan Pasal 53 ayat (2) Undang-Undang Nomor 5 Tahun 1986 tentang Peradilan Tata Usaha Negara, sebagaimana telah diubah beberapa kali, terakhir dengan Undang-Undang Nomor 51 Tahun 2009 tentang Perubahan Kedua Undang-Undang Nomor 5 Tahun 1986 tentang Peradilan Tata Usaha Negara, alat uji Keputusan Tata Usaha Negara tidak hanya peraturan perundang-undangan yang berlaku, namun juga harus memperhatikan asas-asas umum pemerintahan yang baik/layak.

Terhadap sengketa kepegawaian yang timbul akibat penjatuhan hukuman disiplin PNS tersebut di atas, perlu adanya pemahaman mengenai hak-hak dan upaya-upaya yang dapat di-

\footnotetext{
${ }^{7}$ Penulis lebih memilih istilah asas-asas umum pemerintahan yang "layak" dari pada "baik", karena baik belum tentu layak. Sebaliknya layak sudah tentu baik. Walaupun di dalam UndangUndang Nomor 28 Tahun 1999 tentang Penyelenggara Negara Yang Bersih dan Bebas Dari Korupsi, Kolusi, dan Nepotisme.
}

tempuh oleh PNS dalam menghadapi tindakan sewenang-wenang (willekeur) atau tindakan melampaui kewenangan (ultra vires) yang dilakukan oleh organ jabatan tata usaha negara. Materi tulisan ini sengaja dibatasi pada sengketa kepegawaian yang timbul dari pelanggaran disiplin PNS, karena sengketa kepegawaian yang paling banyak terjadi adalah sengketa kepegawaian yang disebabkan oleh pelanggaran disiplin.

\section{Jenis Keputusan Tata Usaha Negara di Bidang Kepegawaian}

Adapun Keputusan Tata Usaha Negara di bidang kepegawaian yang sering dijumpai antara lain:

1. Keputusan pengangkatan sebagai calon PNS.

2. Keputusan pengangkatan sebagai PNS.

3. Keputusan kepengangkatan.

4. Keputusan pengangkatan dalam jabatan (struktural maupun fungsional).

5. Keputusan pemindahan tugas (mutasi).

6. Keputusan pemberhentian sementara.

7. Keputusan hukuman disiplin.

8. Keputusan pemberhentian PNS dengan hak pensiun.

9. Keputusan pemberhentian PNS atas pemintaan sendiri.

Sedangkan obyek sengketa TUN yang sering terjadi yaitu antara lain sebagai berikut:

1. Keputusan yang berterkaitan dengan masalah pemindahan tugas atau mutasi.

2. Keputusan penempatan PNS yang tidak sesuai dengan kualifikasi pindidikan atau skill.

3. Ketidakadilan dalam pembinaan karier PNS.

4. Keterlambatan proses penyelesaian Keputusan di bidang kepegawaian, seperti masalah kenaikan pangkat dan lain sebagainya.

Ketidakadilan hukuman disiplin yang dijatuhkan, khususnya Keputusan penurunan pangkat, pembebasan dari jabatan, dan masalah pemberhentian PNS. 


\section{Jenis Pelanggaran dan Hukuman Disiplin PNS}

Adapun jenis kewajiban dan larangan bagi PNS menurut Peraturan Pemerintah Nomor 53 Tahun 2010 tentang Disiplin Pegawai Negeri Sipil yaitu sebagai berikut:

\section{Setiap PNS wajib: ${ }^{8}$}

1. Mengucapkan sumpah/janji PNS;

2. Mengucapkan sumpah/janji jabatan;

3. Setia dan taat sepenuhnya kepada Pancasila, Undang-Undang Dasar Negara Republik Indonesia Tahun 1945, Negara Kesatuan Republik Indonesia, dan Pemerintah;

4. Menaati segala ketentuan peraturan perundangundangan;

5. Melaksanakan tugas kedinasan yang dipercayakan kepada PNS dengan penuh pengabdian, kesadaran, dan tanggung jawab;

6. Menjunjung tinggi kehormatan negara, Pemerintah, dan martabat PNS;

7. Mengutamakan kepentingan negara dari pada kepentingan sendiri, seseorang, dan/ atau golongan;

8. memegang rahasia jabatan yang menurut sifatnya atau menurut perintah harus dirahasiakan;

9. Bekerja dengan jujur, tertib, cermat, dan bersemangat untuk kepentingan negara;

10. Melaporkan dengan segera kepada atasannya apabila mengetahui ada hal yang dapat membahayakan atau merugikan negara atau Pemerintah terutama di bidang keamanan, keuangan, dan materiil;

11. Masuk kerja dan menaati ketentuan jam kerja;

12. Mencapai sasaran kerja pegawai yang ditetapkan;

13. Menggunakan dan memelihara barangbarang milik negara dengan sebaik-baiknya;

${ }^{8}$ Pasal 3 Peraturan Pemerintah Nomor 53 Tahun 2010 tentang Disiplin Pegawai Negeri Sipil.
14. Memberikan pelayanan sebaik-baiknya kepada masyarakat;

15. Membimbing bawahan dalam melaksanakan tugas;

16. Memberikan kesempatan kepada bawahan untuk mengembangkan karier; dan

17. Menaati peraturan kedinasan yang ditetapkan oleh pejabat yang berwenang.

\section{Setiap PNS dilarang: ${ }^{9}$}

1. Menyalahgunakan wewenang;

2. Menjadi perantara untuk mendapatkan keuntungan pribadi dan/atau orang lain dengan menggunakan kewenangan orang lain;

3. Tanpa izin Pemerintah menjadi pegawai atau bekerja untuk negara lain dan/atau lembaga atau organisasi internasional;

4. Bekerja pada perusahaan asing, konsultan asing, atau lembaga swadaya masyarakat asing;

5. Memiliki, menjual, membeli, menggadaikan, menyewakan, atau meminjamkan barangbarang baik bergerak atau tidak bergerak, dokumen atau surat berharga milik negara secara tidak sah;

6. Melakukan kegiatan bersama dengan atasan, teman sejawat, bawahan, atau orang lain di dalam maupun di luar lingkungan kerjanya dengan tujuan untuk keuntungan pribadi, golongan, atau pihak lain, yang secara langsung atau tidak langsung merugikan negara;

7. Memberi atau menyanggupi akan memberi sesuatu kepada siapapun baik secara langsung atau tidak langsung dan dengan dalih apapun untuk diangkat dalam jabatan;

8. Menerima hadiah atau suatu pemberian apa saja dari siapapun juga yang berhubungan dengan jabatan dan/atau pekerjaannya;

9. Bertindak sewenang-wenang terhadap bawahannya;

\footnotetext{
${ }^{9}$ Ibid, Pasal 4.
} 
10. Melakukan suatu tindakan atau tidak melakukan suatu tindakan yang dapat menghalangi atau mempersulit salah satu pihak yang dilayani sehingga mengakibatkan kerugian bagi yang dilayani;

11. Menghalangi berjalannya tugas kedinasan;

12. Memberikan dukungan kepada calon Presiden/Wakil Presiden, Dewan Perwakilan Rakyat, Dewan Perwakilan Daerah, atau Dewan Perwakilan Rakyat Daerah dengan cara:

a. Ikut serta sebagai pelaksana kampanye;

b. Menjadi peserta kampanye dengan menggunakan atribut partai atau atribut PNS;

c. Sebagai peserta kampanye dengan mengerahkan PNS lain; dan

d. Sebagai peserta kampanye dengan menggunakan fasilitas lain.

13. Memberikan dukungan kepada calon Presiden/Wakil Presiden dengan cara:

a. Membuat keputusan dan/atau tindakan yang menguntungkan atau merugikan salah satu pasangan calon selama masa kampanye; dan/atau

b. Mengadakan kegiatan yang mengarah kepada keberpihakan terhadap pasangan calon yang menjadi peserta pemilu sebelum, selama, dan sesudah masa kampanye meliputi pertemuan, ajakan, himbauan, seruan, atau pemberian barang kepada PNS dalam lingkungan unit kerjanya, anggota keluarga, dan masyarakat.

14. Memberikan dukungan kepada calon anggota Dewan Perwakilan Daerah atau calon Kepala Daerah/Wakil Kepala Daerah dengan cara memberikan surat dukungan disertai foto kopi Kartu Tanda Penduduk atau Surat Keterangan Tanda Penduduk sesuai peraturan perundangundangan; dan

15. Memberikan dukungan kepada calon Kepala Daerah/Wakil Kepala Daerah, dengan cara: a. Terlibat dalam kegiatan kampanye untuk mendukung calon Kepala Daerah/Wakil Kepala Daerah;

b. Menggunakan fasilitas yang terkait dengan jabatan dalam kegiatan kampanye;

c. Membuat keputusan dan/atau tindakan yang menguntungkan atau merugikan salah satu pasangan calon selama masa kampanye; dan/atau

d. Mengadakan kegiatan yang mengarah kepada keberpihakan terhadap pasangan calon yang menjadi peserta pemilu sebelum, selama, dan sesudah masa kampanye meliputi pertemuan, ajakan, himbauan, seruan, atau pemberian barang kepada PNS dalam lingkungan unit kerjanya, anggota keluarga, dan masyarakat.

Pelanggaran terhadap kewajiban dan larangan tersebut di atas, PNS dapat dikenakan sanksi hukuman disiplin. Namun dari sekian banyak kewajiban dan larangan tersebut, yang paling banyak dilanggar adalah kewajiban masuk kerja sesuai dengan jam kerja. Akibatnya, PNS yang bersangkutan dijatuhkan hukuman disiplin. Adapunhukuman disiplin menurut ketentuan Pasal 7 Peraturan Pemerintah Nomor 53 Tahun 2010 tentang Disiplin Bagi Pegawai Negeri Sipil yaitu sebagai berikut:

1. Hukuman Ringan meliputi:
a. Teguran lisan;
b. Teguran tertulis; dan
c. Pernyataan tidak puas secara tertulis.

2. Hukuman Sedang meliputi:

a. Penundaan kenaikan gaji berkala untuk paling lama satu tahun;

b. Penurunan gaji sebesar satu kali kenaikan gaji berkala untuk paling lama satu tahun; dan

c. Penundaan kenaikan pangkat untuk paling lama satu tahun.

3. Hukuman Berat meliputi:

a. Penurunan pangkat pada pangkat yang 
setingkat lebih rendah untuk paling lama satu tahun;

b. Pembebasan dari jabatan;

c. Pemberhentian dengan hormat tidak atas permintaan sendiri sebagai PNS; dan

d. Pemberhentian dengan tidak hormat sebagai PNS.

\section{Proses Penjatuhan Hukuman Disiplin.}

Pada tingkat pertama pemeriksaan terhadap Pegawai Negeri Sipil yang disangka melakukan pelanggaran disiplin dilakukan secara lisan, apabila menurut hasil pemeriksaan cukup dijatuhi hukuman disiplin ringan, maka pemeriksaan tidak perlu dilanjutkan secara tertulis. Namun demikian apabila dalam pemeriksaan dapat diancam dengan hukuman disiplin sedang atau berat maka pemeriksaan dilanjutkan secara tertulis dan harus dibuat dalam bentuk BAP (berita acara pemeriksaan).

Setelah proses pemeriksaan selesai, langkah selanjutnya adalah membuat Laporan Hasil Pemeriksaan (LHP) kepada pejabat yang berwenang menghukum. Dalam Peraturan Pemerintah Nomor 53Tahun 2010 tidak dikenal keharusan untuk membuat laporan hasil pemeriksaan tetapi sebagai pertanggungjawaban pemeriksa/tim pemeriksa kepada pejabat yang memerintahkan pemeriksaan maka pemeriksa/ tim pemeriksa hendaknya membuat laporan hasil pemeriksaan secara tertulis. Laporan hasil pemeriksaan disusun berdasarkan bukti-bukti yang diperoleh dari hasil pemeriksaan terhadap surat-surat PNS yang bersangkutan, keterangan pihak yang bersangkutan, serta keterangan pihak lain.

Penyampaian hukuman disiplin dilakukan dalam suatu ruang dan dapat dihadiri oleh pejabat yang menangani urusan kepegawaian dan atau pejabat lain dengan syarat pengkat/ jabatannya tidak boleh lebih rendah dari PNS yang dijatuhi hukuman disiplin. Setiap hukuman disiplin yang dijatuhkan terhadap setiap PNS haruslah berbentuk surat keputusan dengan disebutkan pelanggaran disiplin yang dilakukan.

Walaupun wujud pelanggaran disiplin sama, namun modus dan motifnya selalu berbeda, oleh sebab itu tim pemeriksan haruslah melakukan pemeriksaan secara cermat dan hatihati dalam menjatuhkan putusanagar hukuman disiplin yang akan dijatuhkan itu sesuai dengan pelanggaran disiplin yang dilakukan. Sehingga hukuman disiplin itu dapat diterima sesuai rasa keadilan.

\section{Penyelesaian Sengketa Melalui Upaya Administratif}

Sengketa kepegawaian merupakan bagian dari sengketa Tata Usaha Negara (TUN). Namun penyelesaian sengketa kepegawaian memiliki karakteristik tersendiri yang membedakan dengan sengketa tata usaha negara pada umumnya. Sengketa-sengketa di bidang kepegawaian ada yang ditangani secara langsung oleh suatu Peradilan Tata Usaha Negara (Peratun), dan ada pula yang tidak dapat diselesaikan secara langsung oleh Peratun namun terlebih dahulu harus diselesaikan melalui suatu proses yang mirip dengan suatu proses peradilan, yang dilakukan oleh suatu tim atau oleh seorang pejabat di lingkungan pemerintahan.

Proses tersebut di dalam ilmu hukum disebut dengan peradilan semu (peseudo rechtspraak). Dikatakan sebagai peradilan, karena memenuhi unsur-unsur layaknya suatu badan peradilan yaitu adanya peraturan, adanya pihak-pihak yang bersengketa, adanya pejabat yang berwenang menyelesaikan sengketa dan adanya sanksi. ${ }^{10}$ Namun dikatakan semu (peseudo/ quasi), ${ }^{11}$ karena proses peradilan tersebut dilaksanakan di dalam internal lingkungan pemerintahan, tetapi tata caranya sama dengan suatu badan peradilan, kegiatan peradilan dilakukan oleh suatu badan atau komisi atau dewan atau panitia, dan

\footnotetext{
${ }^{10}$ R. Soemitro, Naskah Singkat tentang Peradilan Administrasi di Indonesia,(Bandung: Bina Cipta, 1997), h. 255-256.

${ }^{11}$ Lutfi Efendi, Pokok-Pokok Hukum Administrasi Negara, (Malang: Bayumedia, 2004), h. 97.
} 
bukan dilaksanakan oleh lembaga peradilan independen di luar lingkungan pemerintahan (yudikatif). ${ }^{12}$

Peradilan semu ini disebut dengan Upaya Administratif (administratief beroep), sedangkan untuk sengketa TUN pada umumnya tidak tersedia upaya penyelesaian secara administratif. Yang dimaksud upaya administratif di sini adalah prosedur yang ditempuh oleh PNS apabila ia tidak puas terhadap suatu Keputusan Tata Usaha Negara (KTUN) di lingkungan pemerintahan sendiri. ${ }^{13}$

Biasanya penyelesaian dengan upaya administratif ini yang ditempuh, karena bangsa Indonesia adalah bangsa yang lebih suka caracara musyawarah ketimbang bersengketa di PTUN. ${ }^{14}$ Upaya administratif tersebut dilaksanakan di lingkungan internal pemerintah itu sendiri. Upaya administratif untuk semua sengketa kepegawaian, tetapi hanya sengketa kepegawaian yang penyelesaiannya tersedia upaya administratif, misalnya sengketa kepegawaian akibat pelanggaran disiplin PNS.

Upaya administratif tersebut terdiri dari dua bentuk, yaitu Keberatan dan Banding Administratif. Secara teoritik, Keberatan yaitu penyelesaian sengketa yang dilakukan sendiri oleh Pejabat atau Instansi yang mengeluarkan Keputusan Tata Usaha Negara yang menjadi obyek sengketa, ${ }^{15}$ sedangkan Banding Administratif adalah penyelesaian sengketa yang dilakukan oleh Pejabat atau Instansi atasan atau Instansi lainnya dari yang mengeluarkan Keputusan Tata Usaha Negara. ${ }^{16}$ Selanjutnya apabila belum merasa puas, barulah penyelesaian sengketa melalui Peradilan Tata Usaha Negara dapat ditempuh.

Menurut ketentuan Peraturan Pemerintah Nomor 53 Tahun 2010 tentang Disiplin Pegawai Negeri Sipil, yang dimaksud dengan keberatan adalah upaya administratif yang dapat ditempuh

\section{${ }^{12} \mathrm{Ibid}$.}

13 SF. Marbun, Peradilan Administrasi Negara dan Upaya Administratif di Indonesia, (Yogyakarta: Liberty, 1997), h. 66.

${ }^{14}$ Jum Anggriani, Hukum Administrasi Negara, (Yogyakarta: Graha Ilmu, 2012), h. 180.

${ }^{15}$ SF. Marbun, Peradilan Administrasi..., h. 67.

${ }^{16}$ Ibid. oleh PNS yang tidak puas terhadap hukuman disiplin yang dijatuhkan oleh pejabat yang berwenang menghukum kepada atasan pejabat yang berwenang menghukum. ${ }^{17}$ Sementara yang dimaksud dengan Banding Administratif adalah upaya administratif yang dapat ditempuh oleh PNS yang tidak puas terhadap hukuman disiplin berupa pemberhentian dengan hormat tidak atas permintaan sendiri atau pemberhentian tidak dengan hormat sebagai PNS yang dijatuhkan oleh pejabat yang berwenang menghukum, kepada Badan Pertimbangan Kepegawaian (Bapek). ${ }^{18}$

Agak berbeda dengan ketentuan tersebut, S.F Marbun dalam Ridwan HR, menjelaskan ciri-ciri dari Banding Administratif yaitu sebagai berikut: ${ }^{19}$

a. Pihak yang memutus adalah Badan Tata Usaha Negara yang secara hierarki lebih tinggi daripada Tata Usaha Negara yang memberi keputusan paertama atau Badan Tata Usaha Negara lain;

b. Badan TataUsaha Negara yang memeriksa Banding Administratif atau pernyataan keberatan dapat mengubah atau mengganti keputusan Badan Tata Usaha Negara yang pertama;

c. Penilaian terhadap keputusan Tata Usaha Negara pertama itu dapat dilakukan secara lengkap, baik dari segi rechtmatigheids (penerapan hukum) maupun dari segi doelmatigheids (aspek kebijaksanaan atau ketepatgunaan). Keputusan Tata Usaha Negara itu tidak hanya dinilai berdasarkan normanorma yang zakelijk, tetapi kepatutan yang berlaku di masyarakat, harus merupakan bagian penilaian atas keputusan itu;

d. Perubahan-perubahan keadaan sejak saat diambilnya keputusan oleh Badan Tata Usaha Negara pertama dan perubahan-perubahan

${ }_{17}$ Pasal 1 Angka 7 Peraturan Pemerintah Nomor 53 Tahun 2010 tentang Disiplin Pegawai Negeri Sipil.

${ }^{18} \mathrm{Ibid}$, Pasal 1 Angka 8.

19 Ridwan HR, Hukum Administrasi Negara, (Jakarta: Rajawali Pers, 2007), h. 304-305. 
kedaan yang terjadi selama proses pemeriksaan banding berjalan harus diperhatikan.

Dengan demikian jika merujuk pada teori, keberatan yang dimaksud dalam Peraturan Pemerintah Nomor 53 Tahun 2010 tentang Disiplin Pegawai Negeri Sipil adalah banding administratif, sementara yang dimaksud banding adalah banding administratif menurut teori, dengan kata lain sejalan dengan teori.

\section{Penyelesaian Sengketa Kepegawaian Melalui Keberatan.}

Hukuman disiplin yang dapat diajukan upaya administratif dalam bentuk Keberatan adalah yang dijatuhkan oleh: ${ }^{20}$

a. Pejabat strukturan Eselon I dan pejabat yang setara ke bawah untuk hukuman disiplin sedang berupa:

1) Penundaan kenaikan gaji berkala selama 1 (satu) tahun; dan

2) Penundaan kenaikan pangkat selama 1 (satu) tahun.

b. Sekretaris Daerah/pejabat struktural Eselon II kabupaten/kota ke bawah/pejabat yang setara ke bawah, untuk jenis hukuman disiplin sedang berupa:

1) Penundaan kenaikan gaji berkala selama 1 (satu) tahun; dan

2) Penundaan kenaikan pangkat selama 1 (satu) tahun.

c. Pejabat struktural Eselon II ke bawah di lingkungan instansi vertikal dan unit setara dengan sebutan lain yang atasan langsungnya pejabat struktural Eselon I yang bukan PPK, untuk jenis hukuman disiplin sedang berupa:

1) Penundaan kenaikan gaji berkala selama 1 (satu) tahun; dan

2) Penundaan kenaikan pangkat selama 1 (satu) tahun.

${ }^{20}$ Lampiran Peraturan Badan Kepegawaian Negara Nomor 21 Tahun 2010 tentang Ketentuan Pelaksanaan Peraturan Pemerintah Nomor 53 Tahun 2010 tentang Disiplin Pegawai Negeri Sipil. d. Pejabat struktural Eselon II ke bawah di lingkungan instansi vertikal dan kantor perwakilan provinsi dan unit setara dengan sebutan lain yang berada di bawah dan bertanggungjawab kepada PPK, untuk jenis hukuman sedang berupa:

1) Penundaan kenaikan gaji berkala selama 1 (satu) tahun; dan

2) Penundaan kenaikan pangkat selama 1 (satu) tahun.

e. Pejabat struktural Eselon II di lingkungan instansi vertikal dan unit setara dengan sebutan lain yang atasan langsungnya pejabat struktural Eselon I yang bukan PPK dan yang berada di bawah dan bertanggungjawab kepada PPK, untuk jenis hukuman disiplin sedang berupa penurunan pangkat setingkat lebih rendah selama 1 (satu) tahun.

Terhadap hukuman disiplin tersebut di atas, Keberatan diajukan dalam jangka waktu 14 (empat belas) hari (bukan hari kerja, tapi hari kalender) sejak keputusan penjatuhan hukuman disiplin, apabila Keberatan diajukan melebihi jangka waktu tersebut, maka Keberatan tersebut tidak dapat diterima. Keberatan tersebut diajukan secara tertulis kepada Atasan Pejabat yang berwenang menghukum dengan memuat alasan Keberatan dan tembusannya disampaikan kepada pejabat yang berwenang menghukum, dan Pejabat yang berwenang menghukum tersebut harus memberikan tanggapan atas Keberatan yang diajukan oleh PNS yang bersangkutan dalam jangka waktu 6 (enam) hari kerja terhitung mulai tanggal yang bersangkutan menerima tembusan surat Keberatan. Apabila dalam jangka waktu tersebut, pejabat yang berwenang menghukum tidak memberikan tanggapan atas Keberatan maka atasan pejabat yang berwenang menghukum mengambil keputusan berdasarkan data yang ada dan jika diperlukan demi obyektifitas dan demi teraksananya asas audi alterm partem, maka dapat memanggil dan/atau meminta keterangan dari pejabat yang berwenang menghukum, PNS yang dijatuhi hukuman disiplin, dan/atau pihak lain yang dianggap perlu. 
Atasan pejabat yang berwenang menghukum wajib mengambil keputusan atas keberatan yang diajukan oleh PNS yang bersangkutan dalam jangka waktu 21 (dua puluh satu) hari kerja terhitung mulai tanggal yang bersangkutan menerima surat keberatan. Keputusan terhadap permohonan Keberatan tersebut dapat bersifat memperkuat, memperingan, memperberat, atau membatalkan hukuman disiplin yang dijatuhkan sebelumnya. Keputusan atas Keberatan tersebut bersifat final dan mengikat. Apabila dalam waktu lebih 21 (dua puluh satu) hari kerja Atasan Pejabat yang berwenang menghukum tidak mengambil keputusan atas Keberatan maka keputusan pejabat yang berwenang menghukum batal demi hukum. Dengan demikian, sikap diam dari Atasasn Pejabat yang berwenang menghukum tersebut disamakan dengan maksud menerima/mengabulkan, keputusan yang demikian dikenal dengan sebagai keputusan fiktif positif. ${ }^{21}$

\section{Penyelesaian Sengketa Kepegawaian Melalui Banding Administratif}

PNS yang dijatuhi hukuman disiplin oleh Pejabat Pembina Kepegawaian (PPK) dan Gubernur sebagai wakil pemerintah berupa pemberhentian dengan hormat tidak atas permintaan sendiri sebagai PNS dan pemberhentian tidak dengan hormat sebagai PNS dapat mengajukan Banding Administratif kepada Badan Pertimbangan Kepegawaian (Bapek).

Badan Pertimbangan Kepegawaian merupakan suatu badan yang berkedudukan dibawah dan bertanggunjawab kepada Presiden yang salah satu tugasnya memeriksa dan mengambil keputusan mengenai keberatan yang diajukan oleh PNS yang berpangkat pembina, golongan ruang IV/a ke bawah, tentang hukuman disiplin yang dijatuhkan kepadanya berdasarkan Peraturan Pemerintah Nomor 53 Tahun 2010 sepanjang mengenai hukuman disiplin pemberhentian dengan hormat tidak atas perminta-

${ }^{21}$ Ade Kosasih, Formula Praktis Memahami Teknik \& Desain Legal Drafting, (Bogor: Herya Media, 2015), h. 25. an sendiri dan pemberhentian dengan tidak hormat sebagai Pegawai Negeri Sipil.

Bapek ini terdiri dari Menteri yang bertanggungjawab dalam bidang Pengawasan Pembangunan dan Pendayagunaan Aparatur Negara (Menpan) sebagai Ketua merangkap Anggota, Kepala Badan Kepegawaian Negara (Kepala BKN) selaku Sekretaris merangkap Anggota, Menteri Sekretaris Kabinet (Menseskab), Jaksa Agung, Kepala Badan Intelijen Negara (Kepala BIN), Dirjend Hukum dan HAM, dan Ketua Dewan Pengurus Nasional Korpri (Ketua DPN Korpri). ${ }^{22}$ Untuk mendukung kelancaran tugas Badan Pertimbangan Kepegawaian tersebut dibentuk Sekretariat Bapek.

Banding Administratif tersebut diajukan secara tertulis kepada Bapek paling lama 14 (empat belas) hari sejak tanggal keputusan hukuman disiplin diterima dan tembusannya disampaikan kepada PPK atau Gubernur selaku wakil Pemerintah yang memuat alasan serta bukti sanggahan. Banding Administratif yang diajukan melebihi tenggang waktu 14 (empat belas) hari tidak dapat diterima. ${ }^{23}$

PPK atau Gubernur wajib memberikan tanggapan dan/atau bukti pelanggaran disiplin yang disampaikan kepada Bapek paling lama 21 (dua puluh satu) hari kerja sejak tanggal diterimanya tembusan Banding Administratif. Apabila PPK atau Gubernur tidak memberikan tanggapan dalam waktu tersebut, maka Bapek mengambil keputusan terhadap Banding Administratif berdasarkan bukti yang ada. ${ }^{24}$ Apabila dianggap perlu, Bapek berwenang meminta keterangan tambahan dari PNS yang bersangkutan, pejabat atau pihak lain yang dianggap perlu.

Bapek wajib memeriksa dan mengambil keputusan dalam waktu paling lama 180 (seratus delapan puluh) hari sejak diterimanya per-

${ }^{22}$ Pasal 4 ayat (2) Peraturan Pemerintah Nomor 24 Tahun 2011 tentang Badan Pertimbangan Kepegawaian.

${ }^{23}$ Ibid, Pasal 7.

${ }^{24}$ Ibid, Pasal 8. 
mohonan Banding Administratif. ${ }^{25}$ Keputusan tersebut diambil melalui sidang Bapek yang dihadiri paling sedikit Ketua, Sekretaris dan minimal 3 (tiga) orang anggota. ${ }^{26}$ Dalam sidang tersebut, keputusan diambil secara musyawarah untuk mufakat. Dalam hal musyawarah untuk mufakat tidak tercapai, maka keputusan diambil berdasarkan suara terbanyak (voting). ${ }^{27}$

Keputusan Bapek tersebut dapat bersifat menguatkan, memperberat, memperingan atau membatalkanhukuman disiplin tersebut melalui surat keputusan yang ditandatangani oleh Ketua dan Sekretaris. Apabila PNS yang bersangkutan merasa tidak puas atas keputusan tersebut dapat mengajukan gugatan kepada Peradilan Tata Usaha Negara. ${ }^{28}$

\section{Penyelesaian Sengketa Kepegawaian Melalui Peradilan Tata Usaha Negara.}

Secara historis sebelum Undang-Undang Nomor 5 Tahun 1986 tentang Peradilan Tata Usaha Negara dibentuk, Undang-Undang Nomor 8 Tahun 1974 tentang Pokok-Pokok Kepegawaian sudah mengatur peradilan yang menyelesaikan sengketa kepegawaian. Hal ini dapat dilihat dalam Pasal 35 yang berbunyi: "Penyelesaian sengketa di bidang kepegawaian dilakukan melalui peradilan untuk itu, sebagai Peradilan Tata Usaha Negara yang dimaksud dalam Undang-Undang Nomor 14 Tahun 1970 tentang Ketentuan-Ketentuan Pokok Kekuasaan Kehakiman".

Setelah terbitnya Undang-Undang Nomor 5 Tahun 1986 tentang Peradilan Tata Usaha Negara, sengketa kepegawaian diatur secara tegas sebagai bagian dari kompetensi absolut Peradilan Tata Usaha Negara. Hal ini dapat dilihat dalam Pasal 1 angka 4 yang menyebutkan bahwa: "Sengketa Tata Usaha Negara adalah sengketa yang timbul dalam bidang tata usaha negara antara orang atau badan hukum perdata

\footnotetext{
${ }^{25}$ Ibid, Pasal 9.

${ }^{26}$ Ibid, Pasal 10.

${ }^{27}$ Ibid, Pasal 11.

${ }^{28}$ Ibid.
}

dengan badan atau pejabat tata usaha negara, baik di pusat maupun di daerah, sebagai akibat dikeluarkannya keputusan tata usaha negara, termasuk sengketa kepegawaian berdasarkan peraturan perundang-undangan yang berlaku". Bahkan setelah dilakukan perubahan terhadap Undang-Undang Nomor 8 Tahun 1974 tentang Pokok-Pokok Kepegawaian melalui UndangUndang Nomor 43 Tahun 1999, Pasal 35 diubah menjadi 3 (tiga) ayat, yang ayat (1) menetukan bahwa: "Sengketa kepegawaian diselesaikan melalui Peradilan Tata Usaha Negara". Sementara di dalam Undang-Undang Nomor 5 Tahun 2014 tentang Aparatur Sipil Negara tidak menunjuk secara tegas lingkungan peradilan yang berwenang menyelesaikan sengketa kepagawaian. Namun, landasan hukum kompetensi Peradilan Tata Usaha Negara cukup berdasarkan ketentuan Pasal 1 Angka 4 Undang-Undang Nomor 5 Tahun 1986 tentang Peradilan Tata Usaha Negara.

Hubungan korelasi antara Upaya Administratif dengan Peradilan Tata Usaha Negara dapat dilihat pada Pasal 48 ayat (1) Undang-Undang Nomor 5 Tahun 1986 tentang Peradilan Tata Usaha Negara menentukan bahwa "Dalam hal suatu badan hukum atau Pejabat Tata Usaha Negara diberi wewenang atau berdasarkan peraturan perundang-undangan untuk menyelesaikan sengketa tata usaha negara tertentu, maka sengketa Tata Usaha Negara tersebut harus diselesaikan melalui upaya administratif yang tersedia”. Sedangkan ayat (2) mengatur bahwa "Pengadilan baru berwenang memeriksa, memutus dan menyelesaikan sengketa tata usaha negara sebagaimana dimaksud dalam ayat (1) jika seluruh upaya administratif yang bersangkutan telah digunakan".

Namun perlu diperhatikan di sini adalah Surat Edaran Mahkamah Agung Nomor 2 Tahun 1991 yang memberikan petunjuk kepada badan Peradilan Tata Usaha Negara dalam menyelesaikan sengketa tata usaha negara yang terdapat upaya administratif. Petunjuk tersebut yaitu:

1. Jika dalam peraturan perundang-undangan 
yangmenjadidasardikeluarkannya Keputusan Tata Usaha Negara yang mengakibatkan terjadinya sengketa Tata Usaha Negara upaya administratif yang tersedia adalah Keberatan, maka penyelesaian selanjutnya adalah dengan mengajukan gugatan ke Pangadilan Tata Usaha Negara (PTUN).

2. Jika dalam peraturan perundang-undangan yang menjadi dasar dikeluarkannya Keputusan Tata Usaha Negara yang mengakibatkan terjadinya sengketa Tata Usaha Negara upaya administratif yang tersedia adalah Banding Administratif saja atau Keberatan dan Banding Administratif, maka penyelesaian selanjutnya adalah dengan mengajukan gugatan ke Pangadilan Tinggi Tata Usaha Negara (PTTUN).

Namun jika dikaji lebih mendalam terhadap penyelesaian sengketa kepegawaian, maka apabila Banding Administratif telah ditempuh, selanjutnya diajukan gugatan langsung ke Pengadilan Tinggi Tata Usaha Negara (PTTUN) bukan ke PTUN. Oleh karena dalam sengketa kepegawaian yang hanya tersedia Banding Administratif kepada Bapek diajukan gugatan ke PTTUN. Jadi dalam konteks ini, PTTUN adalah pengadilan tingkat pertama bukan tingkat banding.

Pada saat akan mengajukan gugatan sengketa kepegawaian ke Peradilan Tata Usaha Negara (baik PTUN maupun PTTUN) ada hal-hal yang perlu diperhatikan:

\section{Upaya administratif.}

Jika upaya administratif (Keberatan/ Banding Administratif) tersedia, maka sebelum mengajukan gugatan harus menempuh upaya administratif yang tersedia, agar gugatan tidak prematur, karena jika gugatan prematur akan menyebabkan gugatan tidak dapat diterima (niet on kelijk verklaark).

2. Tenggang waktu mengajukan gugatan.

Di dalam sengketa tata usaha negara tenggang waktu mengajukan gugatan ditentukan secara limitatif. Adapun tenggang waktu yang dimaksud adalah 90 hari sejak diterimanya atau diumumkannya Keputusan Tata Usaha Negara yang menjadi obyek sengketa. Dengan demikian, diambil kesimpulan bahwa tenggang waktu gugatan yang disediakan apabila tidak puas terhadap keputusan upaya administratif, maka dihitung sejak saat diterimanya keputusan dari Pejabat atau Instansi yang mengeluarkan keputusan (jika upaya administratif yang tersedia hanya Keberatan), atau sejak saat diterima keputusan dari Pejabat atasan atau instansi atasan atau instansi lain yang berwenang (jika upaya administratif hanya berupa banding administratif saja atau berupa Keberatan dan Banding Administratif). Jika tenggang waktu tidak diperhatikan sehingga daluarsa (vriajring) sudah lewat 90 (sembilan puluh) dapat menyebabkan gugatan tidak dapat diterima (niet on kelijk verklaark).

3. Gugatan harus ditujukan kepada pengadilan yang berwenang.

Dalam mengajukan gugatan harus dilakukan secara tertulis dan ditujukan kepada pengadilan yang berwenang, yaitu kepada pengadilan tempat kedudukan tergugat(actor squitor forum rei). Apabila tergugat lebih dari satu dan berkedudukan tidak dalam satu daerah hukum, maka gugatan diajukan kepada pengadilan tempat salah satu tergugat. Sedangkan jika tergugat tidak berada dalam daerah hukum pengadilan tempat kediaman penggugat, maka gugatan dapat diajukan kepada pengadilan tempat kediaman penggugat untuk selanjutnya diteruskan kepada pengadilan yang bersangkutan. Khusus terhadap tergugat yang berada di luar negeri, gugatan diajukan kepada Pengadilan Tata Usaha Negara Jakarta. Gugatan yang diajukan tidak memperhatikan kompetensi relatif juga menyebabkan gugatan tidak dapat diterima (niet on kelijk verklaark).

4. Di dalam sengketa kepegawaian, tuntutan gugatan terhadap Keputusan Tata Usaha Negara yang menimbulkan terjadinya sengketa kepegawaian dapat berupa per- 
mohonan kepada pengadilan untuk menyatakan Keputusan tersebut tidak sah atau batal dan dapat disertai dengan tuntutan ganti kerugian dan/atau rehabilitasi.

5. Apabila Putusan PTTUN masih tidak memberikan kepuasan kepada PNS yang bersangkutan, maka dalam jangka waktu paling lambat 14 (empat belas) hari dapat mengajukan kasasi kepada Mahkamah Agung.

Setelah hal-hal tersebut diperhatikan, maka surat gugatan dapat diajukan kepada Peratun. Gugatan tersebut haruslah dibuat secara tertulis dengan memuat identitas para pihak, hak gugat (legal standing) yang menguraikan kedudukan Penggugat dan obyek sengketa, dasar atau alasan gugatan (fundamentum petendi atau posita), dan amar tuntutan (petitum).

Sebenarnya legal standing bukan syarat mutlak dalam sistematika surat gugatan, namun perlu juga kiranya dimuat untuk memperkuat posita, karena dalam hukum acara Peratun dan Perdata ada prinsip no interest no suit (tidak ada kepentingan, maka tidak ada sengketa). Pada bagianposita harus menguraikan peristiwa hukum dan dasar gugatan secara runut, rinci, dan jelas, karena jika dasar gugatan tidak jelas atau kabur (obscuur libel) maka akan menyebabkan gugatan tidak dapat diterima (niet on kelijk verklaark). Sedangkan untuk petitum pada prinsipnya memuat permohonan agar keputusan yang menjadi obyek sengketa dinyatakan batal atau tidak sah.

Istilah "batal" dalam konteks putusan yang "prospektif" atau bersifat ex nunc atau pro futuro, yaitu putusan tersebut berlaku ke depan. ${ }^{29}$ Dengan kata lain, keputusan tersebut dipandang sebagai sesuatu yang sah sampai saat dinyatakan "batal" (dibatalkan), sehingga akibatakibat hukum dari keputusan yang dibatalkan tersebut tetap diakui atau sah menurut hukum. Adapun cacat yuridis yang menyebabkan suatu keputusan menjadi batal meliputi cacat

${ }^{29}$ Bagir Manan, Kekuasaan Kehakiman RepublikIndonesia, (Bandung: Universitas Islam Bandung Press, 1995), h. 31. wewenang, prosedur, dan/atau substansi. ${ }^{30}$

Untuk keputusan yang dinyatakan tidak sah (nullity) berlaku surut "retroaktif" terhitung dari saat dikeluarkannya keputusan itu atau bersifat ex tunc. Dengan kata lain keputusan dinyatakan tidak sah dikeluarkan karena tidak sesuai dengan hukum atau melawan hukum. ${ }^{31}$ Adapun penyebab suatu keputusan tidak sah apabila dibuat oleh Badan atau Pejabat yang tidak berwenang, dibuat oleh Badan atau Pejabat yang melampaui kewenangannya (ultra vires), dan/atau dibuat oleh Badan dan/ atau Pejabat yang bertindak sewenang-wenang (willekeur). ${ }^{32}$

Setelah surat gugatan diajukan ke Peratun yang berwenang melalui kepaniteraannya dan sudah melalui tahapan penelitian administratif, maka akan dilakukan rapat permusyawaratan yang dikenal dengan sebutan dismissal procedur (prosedur yang disederhanakan) dan pemeriksaan persiapan dalam sidang yang tertutup. Dismissal procedur untuk memeriksa pokok gugatan apakah merupakan kompetensi Peratun atau tidak, termasuk juga masalah tenggang waktu mengajukan gugatan, alasan gugatan dan tuntutan. Tahapan dismissal prosedur ini hanya ada di dalam hukum acara Peratun dan tidak ditemui di dalam hukum acara perdata.

Pada tahapan dismissal procedur Ketua Pengadilan berwenang untuk mengeluarkan penetapan dismissal mengenai gugatan dinyatakan tidak dapat diterima (niet on kelijk verklaark) atau tidak berdasar (niet gegrond). Jika pada tahap dismissal procedur telah dilewati maka masuk tahapan pemeriksaan persiapan yang bertujuan untuk menyempurnakan surat gugatan melalui petunjuk-petunjuk hakim.

Apabila tahapan-tahapan tersebut telah dilalui, maka dilakukan pemeriksaan persidangan dengan tahapan-tahapan sebagai berikut:

1. Pembacaan surat gugatan;

\footnotetext{
${ }^{30}$ Ade Kosasih, Formula Praktis ..., h. 23-24.

31 Irfan Fachruddin, Pengawasan Peradilan Administrasi Terhadap Tindakan Pemerintah, (Bandung: Alumni, 2005), h. 243.

${ }^{32}$ Ade Kosasih, "Formula Praktis..., h. 24.
} 
2. Jawaban (yang dapat memuat nota keberatan/ tangkisan/eksepsi);

3. Replik;

4. Duplik;

5. Pemeriksaan alat bukti;

6. Kesimpulan para pihak; dan

7. Putusan (vonis).

Apabila para pihak tidak puas terhadap putusan pengadilan tingkat pertama (PTUN untuk sengketa kepegawaian yang hanya melalui upaya Keberatan Administratif dan PTTUN untuk sengketan kepegawaian yang melalui upaya Banding Administratif) dapat mengajukan upaya hukum banding (appeal) dan apabila masih juga tidak puas dapat mengajukan kasasi. Namun khusus terhadap obyek sengketa berupa keputusan pejabat daerah yang hanya berlaku di daerah yang bersangkutan saja tidak dapat diajukan kasasi. ${ }^{33}$

\section{Penutup}

Berdasarkan uraian tersebut di atas, dapat dismpulkan bahwa penyelesaian sengketa di bidang kepegawaian yang timbul akibat penjatuhan hukuman disiplin memiliki jalur yang beraneka ragam berdasarkan pelanggaran disiplin yang dilakukan, jenis hukuman yang dijatuhkan, dan jenjang jabatan pejabat yang berwenang menghukum. Jalur-jalur tersebut yaitu ada yang melalui upaya Keberatan Administratif dan Banding Administratif. Jika yang dilaluinya hanya Keberatan, maka tahapan selanjutnya adalah pengajuan gugatan ke PTUN, sedangkan jika tahapan yang dilaluinya adalah Banding Administratif, maka gugatan tingkat pertama diajukan kepada PTTUN sebagai pengadilan tingkat pertama.

Dengan mencermati karakteristik dan ke-

${ }^{33}$ Pasal 45A Undang-Undang Nomor 5 Tahun 1986 tentang Peradilan Tata Usaha Negara Jo. Undang-Undang Nomor 9 Tahun 2004 tentang Perubahan Atas Undang-Undang Nomor 5 Tahun 1986 tentang Peradilan Tata Usaha Negara Jo. UndangUndang Nomor 51 Tahun 2009 tentang Perubahan Kedua Atas Undang-Undang Nomor 5 Tahun 1986 tentang Peradilan Tata Usaha Negara. anekaragaman penyelesaian sengketa kepegawaian yang timbul akibat penjatuhan hukuman disiplin, maka sebaiknya sebelum mengajukan gugatan ke pengadilan, Penggugat harus mempelajari ketentuan peraturan perundang-undangan yang berlaku, khususnya peraturan disiplin PNS untuk mengetahui jalur-jalur atau tahapan penyelesaian sengketa yang benar, agar gugatan yang akan diajukan ke Peratun tidak dinyatakan tidak dapat diterima (niet on kelijk verklaark).

\section{Pustaka Acuan}

Kosasih, Ade, Formula Praktis Memahami Teknik \& Desain Legal Drafting, (Bogor: Herya Media, 2015).

Manan, Bagir, Kekuasaan Kehakiman Republik Indonesia, (Bandung: Universitas Islam Bandung Press, 1995).

Fachruddin, Irfan, Pengawasan Peradilan Administrasi Terhadap Tindakan Pemerintah, (Bandung: Alumni, 2005).

Anggriani, Jum, Hukum Administrasi Negara, (Yogyakarta: Graha Ilmu, 2012).

Effendi, Lutfi, Pokok-Pokok Hukum Administrasi, (Malang: Bayu Media, 2004).

Marbun, S.F., Peradilan Administrasi Negara dan Upaya Administratif di Indonesia, (Yogyakarta: Liberty, 1997).

Muchsan, Pengantar Hukum Administrasi Negara, (Yogyakarta: Liberty, 1982).

Hadjon, Philipus M., Pengantar Hukum Administrasi Indonesia, (Yogyakarta: UGM Press, 2003).

Ridwan, H.R., Hukum Administrasi Negara, (Jakarta: Rajawali Perss, 2007).

Sekretariat Negara Republik Indonesia, Risalah Persidangan BPUPKI dan PPKI tanggal 28 Mei - 22 Agustus 1995, (Jakarta: Sekretariat Negara, 1995).

Soemitro, R., Naskah Singkat tentang Peradilan Administrasi di Indonesia,(Bandung: Bina Cipta, 1997).

Sri, Pudyatmoko, Y., Hukum Administrasi Negara, (Yogyakarta: Atma Jaya, 2012). 
Wiyono, R., Hukum Acara Peradilan Tata Usaha Negara, (Jakarta: Sinar Grafika, 2005).

\section{Peraturan Perundang-Undangan:}

Undang-Undang Nomor 5 Tahun 1986 tentang Peradilan Tata Usaha Negara.

Undang-Undang Nomor 8 Tahun 1974 tentang Pokok-Pokok Kepegawaian.

Undang-Undang Nomor 28 Tahun 1999 tentang Penyelenggara Negara Yang Bersih dan Bebas Dari Korupsi, Kolusi, dan Nepotisme.

Undang-Undang 43Tahun 1999 tentang Perubahan Atas Undang-Undang Nomor 8 Tahun 1974 tentang Pokok-Pokok Kepegawaian.

Undang-Undang Nomor 9 Tahun 2004 tentang Perubahan Atas Undang-Undang Nomor 5 Tahun 1986 tentang Peradilan Tata Usaha Negara.
Undang-Unang Nomor 51 Tahun 2009 tentang Perubahan Kedua Atas Undang-Undang Nomor 5 Tahun 1986 tentang Peradilan Tata Usaha Negara.

Undang-Undang Nomor 5 Tahun 2014 tentang Aparatur Sipil Negara.

Peraturan Pemerintah Nomor 42 Tahun 2004 tentang Pembinaan Jiwa Korps dan Kode Etik Pegawai Negeri Sipil.

Peraturan Pemerintah Nomor 53 Tahun 2010 tentang Peraturan Disiplin Pegawai Negeri Sipil.

Peraturan Pemerintah Nomor 24 Tahun 2011 tentang Badan Pertimbangan Kepegawaian.

Peraturan Kepala Badan Kepegawaian Negara Nomor 21 Tahun 2010 tentang Ketentuan Pelaksanaan Peraturan Pemerintah Nomor 53 Tahun 2010 tentang Disiplin Pegawai Negeri Sipil.

Surat Edaran Mahkamah Agung Republik Indonesia Nomor2 Tahun 1991. 